\title{
Health Condition of European Beech (Fagus sylvatica L.) According to Provenances in International Provenance Trial
}

\author{
Nevenka Ćelepirović ${ }^{1}$, Sanja Novak Agbaba ${ }^{2}$, Aikaterini Dounavi ${ }^{3}$, Sanja Bogunović ${ }^{1}$, Miran Lanšćak $^{1}$, \\ Marija Gradečki - Poštenjak ${ }^{4}$, Anamarija Jazbec ${ }^{5}$, Heinz Rennenberg ${ }^{6,7}$, Mladen Ivanković1 ${ }^{1,}$
}

(1) Croatian Forest Research Institute, Division of Genetics, Forest Tree Breeding and Seed Science, Cvjetno naselje 41, HR-10450 Jastrebarsko, Croatia; (2) Croatian Forest Research Institute, Division of Forest Protection and Game Management, Cvjetno naselje 41, HR-10450 Jastrebarsko, Croatia; (3) Forest Research Institute of Baden-Württemberg, Department of Forest Protection, Wonnhaldestraße 4, DE-79100 Freiburg, Germany; (4) Croatian Forest Research Institute, Division for Silviculture, Cvjetno naselje 41, HR-10450 Jastrebarsko, Croatia; (5) University of Zagreb, Faculty of Forestry and Wood Technology, Department for Forest Inventory and Management, Svetošimunska 25, HR-10000 Zagreb, Croatia; (6) Albert-Ludwigs-University Freiburg, Institute for Forest Sciences, Chair for Tree Physiology, Georges-Köhler-Allee 53/54, DE-79110 Freiburg, Germany; (7) Center of Molecular Ecophysiology (CMEP), College of Resources and Environment, Southwest University No. 2, Tiansheng Road, Beibei district, 400715 Chongqing, P.R. China
Citation: Ćelepirović N, Novak Agbaba S, Dounavi A, Bogunović S, Lanšćak $L$, Gradečki Poštenjak $M$, Jazbec $A$, Rennenberg H, Ivanković M, 2021. Health Condition of European Beech (Fagus sylvatica L.) According to Provenances in International Provenance Trial. Southeast Eur for 12(2): 93-103. https://doi. org/10.15177/seefor.21-14.

Received: 5 Oct 2021; Revised: 25 Nov 2021; Accepted: 26 Nov 2021; Published online: 18 Dec 2021

* Correspondence: e-mail: mladeni@sumins.hr

\begin{abstract}
The performance of European beech (Fagus sylvatica L.) is severely threatened by abiotic and biotic stresses, but the resilience of its provenances from distinct geographic areas has not been sufficiently studied. Therefore, the performance of European beech was investigated in an international provenance trial consisting of twenty-one natural populations originating from Central Europe and Southeast Europe located on Medvednica Mountain (Croatia). The performance of European beech was investigated by characterizing I) damage types, II) crown damage intensity, III) damage frequency, and IV) clustering of provenances based on damage types. Anthracnose, galls, chewing damages, and aphids were recorded on leaves, and canker on the trunk and branches. The crown damage intensity was minute (less than $10 \%$ ) for all types of disease. Anthracnose was the most common damage, followed in descending order by galls, canker, chewing damages and aphids. When the types of damage were analysed using descriptive statistics (frequency analysis and clustering), significant differences were recorded between provenances $\left(\chi^{2}=322.19, p<0.0001\right)$. European beech provenances were classified into four clusters. Aphids and galls caused the least and the highest damage, respectively, in each cluster, except for Cluster 4, where anthracnose caused the highest damage. The results of this study showed generally good health condition of European beech provenances originating from Central and Southeast Europe in the period of the investigation.
\end{abstract}

Keywords: European beech; pests; diseases; international provenance trial

\section{INTRODUCTION}

European beech (Fagus sylvatica L.) is a deciduous, monoecious, anemophilous tree species in the Fagaceae family. As the dominant tree species in Europe, European beech has a large distribution range extending from Sicily in southern Italy (ca. $37.7 \mathrm{~N}$ ) to Bergen in southern Norway (ca. $60.7 \mathrm{~N}$ ) (Fang et al. 2006). It covers approximately 14 million hectares of forest land in Europe (Wühlisch 2010). In Croatia,
European beech is a native tree species, accounting for 47 percent of the forest area. Its natural structure has been preserved in pure or mixed stands (Vukelić and Rau 1998). Moreover, it has a wide ecological valence at altitudes in Croatia; ranging from the Mediterranean vegetation region at about $20 \mathrm{~m}$ above sea leavel to the sub-mountainous vegetation region at about $1570 \mathrm{~m}$ above sea level (Pilaš et al. 2016). The wide geographical distribution of European beech indicates high adaptability to climatic, local edaphic, 
and soil hydrological parameters (Rennenberg et al. 2004, Bolte et al. 2007, Gessler et al. 2007, Kramer et al. 2010;). Studies on the genetic composition of European beech populations indicated that ecotypes are formed by both local and macroclimatic factors (Gömöry et al. 2007, Ivanković et al. 2008a, 2008b Mátyás et al. 2009). Considering the influence of climatic factors on the distribution range of European beech, climate change-based models predicted that European beech can expand its northern range while losing habitat at its southern distribution area (Bréda et al. 2006, Gessler et al. 2007, Kramer et al. 2010).

The adaptability and growth characteristics of European beech were investigated in a beech provenance trial series. The study was conducted as part of the European Union project "European Network for the Evaluation of the Genetic Resources of Beech for Appropriate Use in Sustainable Forestry Management" (AIR3-CT94-2091) of the Institute of Forest Genetics, Grosshansdorf, Germany (Muhs and Wühlisch 1993, Wühlisch 2008). Croatia contributed to the International Beech Provenance Trial project by supplying beechnuts and by establishing three international European beech provenance trials (Gračan 2001, Ivanković 2010).

European beech is thought to be threatened by changing climatic conditions (Gessler et al. 2007), although it is less affected by severe diseases than other forest tree species (FAO 2009). Still, the damages caused by biotic and abiotic stresses to European beech threaten its survival (Bahnweg et al. 2005, Tomiscek 2006, FAO 2009, Gossner et al. 2014, Unterseher et al. 2016). For example, defoliation of European beech was caused by a combination of climate change, edaphic factors, and various biotic factors (FAO 2009). In addition, sun exposure or logging accidents caused cracks in beech bark accompanied by secondary fungal and insect infestations (Tomiscek 2006). However, fungal colonization was reduced more during the hot and dry seasons than during ozone treatment or sun exposure (Bahnweg et al. 2005). Local stand conditions in interactions with fungi in the phyllosphere, as well as leaf physiology influenced the diversity and composition of the leaf mycobiome (Unterseher et al. 2016). Microclimatic conditions had an important influence on the variability of herbivory (Gossner et al. 2014).

In Croatia, the health condition of European beech is influenced by biotic factors, insects, and fungi. The detected insects were bark beetles (Typhorychus bicolor and Ernoporus fagi), sucking insects (Cryptococcus fagi, Phyllapsis fagi), gall midge (Mikiola fagi), and pests of cambial tissue and woodboring beetles (Trypodendron domesticum), long-horned beetle (Hylecoetus dermestoides), beech buprestid (Agrilus viridis), and small weevil (Rynchaeus fagi) (Hrašovec 2003). The beech fungal diseases included root Phytophthora infection, Nectria bark diseases, leaf diseases, red heart and decay fungi (Diminić 2003, Arač 2010, 2016, Pernek et al. 2011). The drought was identified as the most significant abiotic factor threatening European beech in Croatia (Harapin 2003). Particularly, the predominant climatic parameter affecting the crown condition of European beech trees on Medvednica Mountain were annual temperature and precipitation during the vegetation period (Potočić et al. 2008, Seletković et al. 2009).
The aim of the study was to provide insight into the differences in hypersensitivity to pests and diseases between provenances of international European beech provenance trial, considering local climatic conditions. It investigated: I) damage types, II) crown damage intensity, III) damage frequency, and IV) clustering of provenances based on damage types.

\section{MATERIALS AND METHODS}

\section{Study Site}

International European beech provenance trial is situated on Medvednica Mountain ( $45^{\circ} 53^{\prime} \mathrm{N}, 15^{\circ} 55^{\prime} \mathrm{E}$, elevation $730 \mathrm{~m}$, slope with west-northwest exposure). It consists of twenty-one natural populations (150 plants each) originating from Central Europe (DE, CH, AT, and $\mathrm{HU}$ ) and Southeast Europe (HR, BA, SR, and RO) (Table 1). It was established by the Croatian Forest Research Institute in March 2007 (Ivanković et al. 2008a, 2008b, Bogunović et al. 2020).

\section{Health Status Assessment}

The damage types in the European beech provenance trial were recorded by an overall visual tree assessment in July 2015. The presence of surviving and visually healthy trees was documented. For symptomatic trees, the overall crown, trunk, and branches were assessed for damage types. The damage types were classified according to symptoms caused by insect pests and pathogenic fungi. The following labelling was used for the damage types: colour change and curling of leaves caused by aphids (A), chewing damages $(C D)$, galls $(G)$, anthracnose $(A)$, canker on the branch and trunk (C). The intensity of crown damage types was expressed as a percentage of the affected crown and scaled with an ordinal scale: $1=$ slight crown damage $(<10 \%)$, $2=$ moderate crown damage (10\%-50\%), 3=severe crown damage $(>50 \%)$. Canker infestation on the tree trunk and branch bark was recorded as follows: 0 represented the absence of a canker and 1 represented the presence of a canker.

\section{Data Analyses}

Descriptive statistics were carried out for the variables analysed. The data were calculated as follows and expressed as percentages: (I) survival $=$ surviving trees / total planted tree; (II) health = healthy trees / surviving trees; (III) intensity of damage per provenance = damaged trees / surviving trees, and (IV) average intensity of damage (slight, moderate and severe) of each provenance. The calculations and graphs were performed with Microsoft Excel 2016 (Microsoft Corporation, Redmond, WA, USA). For statistical analyses, the sum of damaged trees per type of damage was calculated regardless of damage intensity. Chi-square statistics was used to test the distribution of damage types between European beech provenances, without data for aphids (Sokal et al. 1995). The data for aphids were excluded from the calculation due to small numbers. The statistical analyses for each type of damage are shown in frequency distribution tables and the mosaic maps. The optimal 
Table 1. Data of the international European beech provenance trial (Medvednica Mountain, Croatia).

\begin{tabular}{|c|c|c|c|c|c|c|}
\hline No. & Provenance label & Provenance name & Country & $\begin{array}{l}\text { Latitude } \\
\text { (N) }\end{array}$ & $\begin{array}{l}\text { Longitude } \\
\text { (E) }\end{array}$ & $\begin{array}{l}\text { Elevation } \\
(\mathrm{m})\end{array}$ \\
\hline 1. & HR24 & Dilj Čaglinski & Croatia & $45^{\circ} 17^{\prime}$ & $18^{\circ} 01^{\prime}$ & 350 \\
\hline 2. & HR25 & Vrani kamen & Croatia & $45^{\circ} 37^{\prime}$ & $17^{\circ} 19^{\prime}$ & 600 \\
\hline 3. & HR26 & Lovrin kal & Croatia & $45^{\circ} 19^{\prime}$ & $14^{\circ} 23^{\prime}$ & 900 \\
\hline 4. & $\mathrm{HR} 27$ & Miletka & Croatia & $45^{\circ} 24^{\prime}$ & $15^{\circ} 01^{\prime}$ & 800 \\
\hline 5. & BA30 & Tajan, Zavidovići & $\begin{array}{l}\text { Bosnia and } \\
\text { Herzegovina }\end{array}$ & $44^{\circ} 23^{\prime}$ & $18^{\circ} 03^{\prime}$ & 700 \\
\hline 6. & $\mathrm{HU} 42$ & Valkonya & Hungary & $46^{\circ} 30^{\prime}$ & $16^{\circ} 45^{\prime}$ & 300 \\
\hline 7. & DE46 & Pfalzgrafenweiler & Germany & $48^{\circ} 46^{\prime}$ & $8^{\circ} 35^{\prime}$ & 700 \\
\hline 8. & DE47 & Schelklingen & Germany & $47^{\circ} 59^{\prime}$ & $9^{\circ} 59^{\prime}$ & 650 \\
\hline 9. & DE48 & Hoellerbach & Germany & $49^{\circ} 01^{\prime}$ & $13^{\circ} 14^{\prime}$ & 755 \\
\hline 10. & DE49 & Hasbruch & Germany & $53^{\circ} 08^{\prime}$ & $8^{\circ} 26^{\prime}$ & 35 \\
\hline 11. & AT56 & Scharnstein & Austria & $47^{\circ} 54^{\prime}$ & $13^{\circ} 96^{\prime}$ & 480 \\
\hline 12. & BA59 & Bugojno Vranica, Bistrica & $\begin{array}{l}\text { Bosnia and } \\
\text { Herzegovina }\end{array}$ & $43^{\circ} 33^{\prime}$ & $17^{\circ} 49^{\prime}$ & 750 \\
\hline 13. & BA60 & Tešanj, Crni Vrh & $\begin{array}{l}\text { Bosnia and } \\
\text { Herzegovina }\end{array}$ & $44^{\circ} 33^{\prime}$ & $17^{\circ} 59^{\prime}$ & 500 \\
\hline 14. & BA61 & $\begin{array}{l}\text { Bosanska Krupa, } \\
\text { Bastra Čorkvaća }\end{array}$ & $\begin{array}{l}\text { Bosnia and } \\
\text { Herzegovina }\end{array}$ & $44^{\circ} 45^{\prime}$ & $16^{\circ} 14^{\prime}$ & 720 \\
\hline 15. & BA62 & Dinara Devrek Tefen & $\begin{array}{l}\text { Bosnia and } \\
\text { Herzegovina }\end{array}$ & $44^{\circ} 06^{\prime}$ & $16^{\circ} 30^{\prime}$ & 950 \\
\hline 16. & RO63 & Alesd & Romania & $47^{\circ} 11^{\prime}$ & $22^{\circ} 15^{\prime}$ & 490 \\
\hline 17. & RO64 & Alba-Iulia & Romania & $46^{\circ} 10^{\prime}$ & $23^{\circ} 05^{\prime}$ & 860 \\
\hline 18. & $\mathrm{CH} 65$ & Sihlwald & Switzerland & $47^{\circ} 12^{\prime}$ & $7^{\circ} 21^{\prime}$ & 1050 \\
\hline 19. & RS66 & Avala & Serbia & $44^{\circ} 23^{\prime}$ & $20^{\circ} 45^{\prime}$ & 475 \\
\hline 20. & RS68 & Fruška gora & Serbia & $45^{\circ} 10^{\prime}$ & $19^{\circ} 55^{\prime}$ & 370 \\
\hline 21. & RS69 & Cer & Serbia & $44^{\circ} 12^{\prime}$ & $19^{\circ} 50^{\prime}$ & 745 \\
\hline
\end{tabular}

number of clusters was identified by hierarchical cluster analysis using complete linkage and Euclidean distance. K-means non-hierarchical cluster analysis was used to determine subsets of European beech provenances based on damage types. All statistical analyses were performed using the STATISTICA 13.5 statistical software (TIBCO Software, Palo Alto, CA, USA). Map generation was done with the QGIS software, version 2.16 (http://qgis.osgeo.org).

\section{Local Climate Condition on Medvednica Mountain}

The Croatian Meteorological and Hydrological Service provided meteorological data (maximum, average and minimum monthly temperatures, monthly precipitation, days with snow and frost) from August 2014 to July 2015, based on records from the state hydro-meteorological station Puntijarka $\left(15^{\circ} 58^{\prime} \mathrm{E}, 45^{\circ} 55^{\prime} \mathrm{N}, 988 \mathrm{~m}\right)$, the closest weather station to the study site. A measure of site aridity proposed by de Martonne (1926) was given by the following relationship: I = 12P/ $(T+10)$, where $I$ was aridity index, and input parameters were local monthly precipitation $(P)$ in millimetres and average temperature $(T)$ in degrees Celsius.
The values of the aridity index $(\boldsymbol{I})$ were estimated according to the scale given by de Martonne (36): Dry $(\mid<10)$; Semi-dry

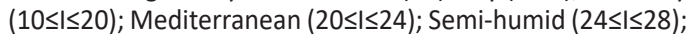
Humid $(28 \leq 1 \leq 35)$; Very Humid $(35 \leq 1 \leq 55)$; Extremely humid $(55<)$. Tables ( $44 \mathrm{a}, \mathrm{b}, \mathrm{c}$ ) showed the meteorological data. These data confirm that the local climate could be described as Cfb according to the Köppen-Geiger climate classification, i.e. as a moderately warm, humid climate with warm summers and differences between the seasons (Zaninović et al. 2008). This climate has been termed „the climate of beech" (Šegota and Filipčić 1996).

\section{RESULTS}

\section{Types of Damage}

The survey of the provenance trial started with determination of the number of surviving and healthy trees to provide data for descriptive statistics. The surviving ranged from $60 \%$ (RO6) to $94.67 \%$ (HU42) and healthy trees ranged from $4.67 \%$ (RO63) to $68.00 \%$ (DE47) (S1). The health 
condition survey of the provenances was performed on the damaged trees. Four types of leaf damage were recorded: colour change and curling caused by aphids, chewing damages, galls, and anthracnose. Bark and wood damages recorded canker on the trunk and on branches. Phyllaphis fagi, a woolly beech aphid, was found on the underside of young beech leaves, causing yellowing and reddening as well as buckling of the leaf margins towards the underside (S2a). The winged and wingless viviparous beech leaf aphids were oval, pale yellow, and covered with dense waxy wool. Leaves chewing damages were present as bitten leaf sections $(\mathrm{S} 2 \mathrm{~b})$ and leaf-mining (S2c). The causal insects of leaf bites and miners can be diagnosed by the mine shape, gallery and blotch. Many Lepidoptera and Coleoptera species produce leaf bites. Oval or elongated mines between veins with green lower epidermis without reticulation were caused by larvae of the moth Phyllonorycter maestingella. Mines that meandered between two lateral veins towards the leaf margin were caused by the larvae of the leaf miner moth Stigmella sp. The miner tunnels were filled with granular faeces. Also, larvae of the leaf miner beetle Orchestes fagi mine the leaves of beech. The mine begins as a duct on the midrib of the leaf and ends in a blotch. Woody, ovoid, unilateral galls (S2g), 4-10 mm long, produced by the beech gall midge Mikiola fagi, were present on the upper surface of beech leaves. Anthracnose disease symptoms on leaves were caused by the fungus Apiognomonia errabunda. The symptoms, i.e. leaf spots, develop from the leaf veins and spread over the leaf (S2e). Canker was observed on branches and the trunk. Symptoms included necrosis, sunken tissue, orange to reddish bark coloration, open canker, and tissue dieback. Twig and branch canker were caused by Nectria cinnabarina (Tode); trunk canker (S2f) by Neonectria ditissima (Tul.). Thus, a total of four damage types were recorded on beach leaves, with three damage types caused by insects and one by a pathogenic fungus. Canker, recorded on the bark of the trunk and on branches, was caused by pathogenic fungi.

The analysis of types of damage per tree showed a prevalence of three damage types. However, in provenances DE47, RS68, RO64, BA6, HU42 and provenance HR27, two and four types of damage per tree were observed, respectively. Trees with five damage types were not observed in this study. In general, trees with one damage type were most common, ranging from 63.92\% (HR27) to 91.43\% (DE47) (Figure 1).

\section{Intensity of Crown Damage}

The survey of the intensity of the European beech crown damage is shown in Figure 2. Eleven provenances were not infested by aphids; ten provenances showed slight crown damage by aphids, except RS66, showing $0.83 \%$ of the trees had severe crown damage (Figure 2a). Although galls were present in each provenance (Figure $2 b$ ), the most moderate and severe crown damage was observed in DE48 and DE46 ( $15.04 \%$ and $46.72 \%$ of the trees, respectively). BA62 was the least affected by galls and showed slight crown damage (7.07\% of the trees). Moderate chewing crown damage was present in the HU42, DE48, RS66, BA62, and BA30 ranging from $0.70 \%$ to $1.41 \%$ of the trees. Severe chewing crown damage occurred in RS66 $(0.83 \%$ of the trees) and BA62 (3.03\% of the trees) (Figure 2c). Slight anthracnose crown damage was present in all provenances up to $48.89 \%$ of the trees (RO63) (Figure 2d). The provenance with the highest percentage of moderate anthracnose crown damage was RO64 (9.32\% of the trees). The most severe anthracnose crown damage was found in BA60 (4.26\% of the trees). Taken together, the lowest and the highest average slight crown damages were related to aphids $(0.59 \%$ of the trees) and anthracnose (31.53\% of the trees), respectively. The lowest average moderate and severe crown damages were related to aphids $(0.00 \%$ and $0.83 \%$ of the trees, respectively). The highest average moderate and severe crown damages were related to galls and anthracnose $(5.63 \%$ and $31.53 \%$ of the trees, respectively). The significant statistical difference between intensities of crown damages was shown: aphids (sample size $=2473, \chi 2=26.430 ; p<0.0001$ ), galls (sample size $=2473, \chi 2=1110.780 ; p<0.0001)$, chewing damages (sample size $=2473, \chi 2=243.950 ; p<0.0001$ ) and anthracnose (sample size $=2473, \chi 2=1.286 ; p<0.0001$ ). Thus, examination of the intensity of crown damage in the provenance trial showed the predominance of slight crown damage (less than $10 \%$ ) in four types of damage (aphids, galls, chewing damages, and anthracnose).

Branch canker was the lowest on the provenance DE49 $(0.78 \%$ of the trees), the highest on HR26 (6.98\% of the trees), and was not present on R064, RS66, and $\mathrm{CH} 65$. Trunk canker was the lowest on DE49 (0.78\% of the trees) and the highest on BA60 (13.83\% of the trees) (Figure 3$)$. The significant statistical difference between intensity of canker on trunk and branch was shown (sample size $=2473$, $\chi 2=37.923 ; p<0.0001)$.

Table 2. Types of damage on European beech trees in the international provenance trial.

Type of damage

Color changing and curling of leaves

Chewing damages on leaves

Galls on leaves

Anthracnose on leaves

Canker on the branch

Canker on the trunk
Cause of the damage (insects and fungi)

Phyllaphis fagi (L.)

Orchestes fagi (L.), Phyllonorycter maestingella (Müller), Stigmella hemargyrel-la (Kollar), Operophtera brumata L., Erranis defoliaria (Clerck)

Mikiola fagi (Hartig)

Apiognomonia errabunda (Rob.) Hohn.

Nectria cinnabarina (Tode)

Neonectria ditissima (Tul.) 


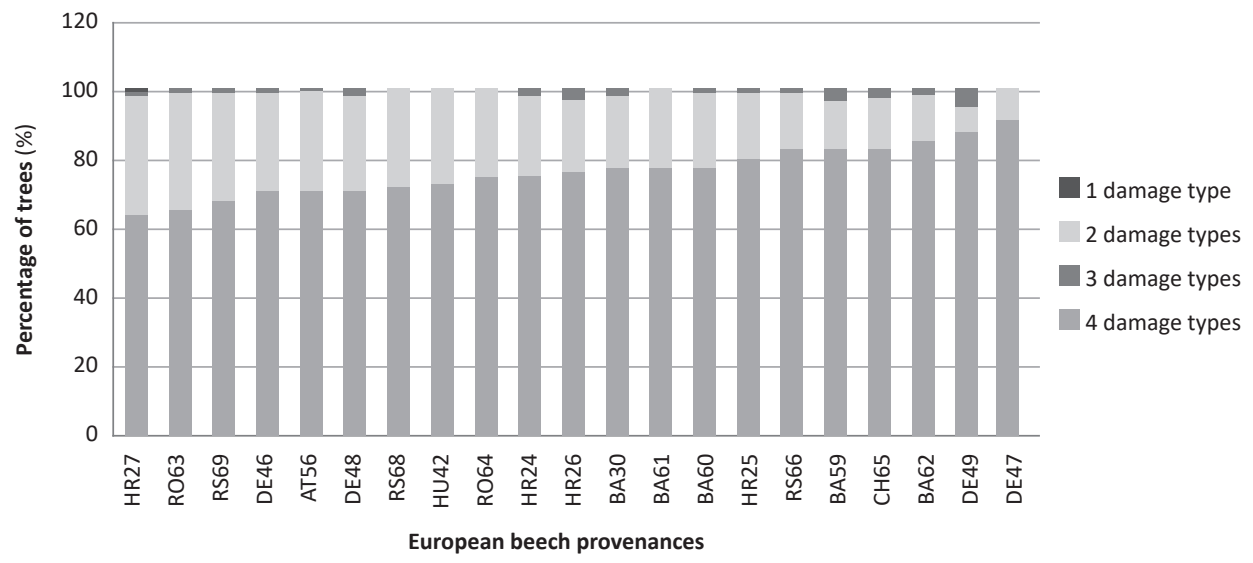

Figure 1. Percentage of trees of European beech provenances damaged by different damage types (Coding label of provenances: see Table 1).

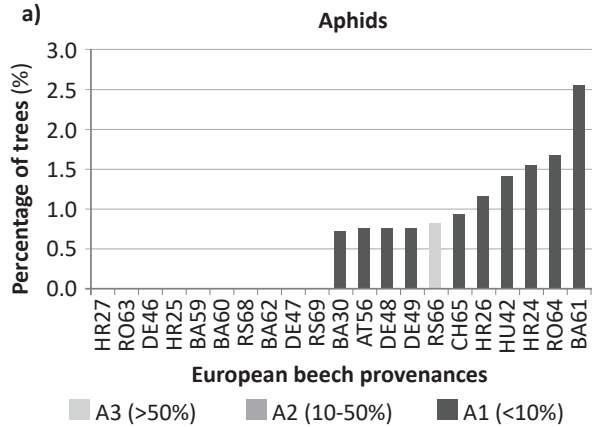

c)

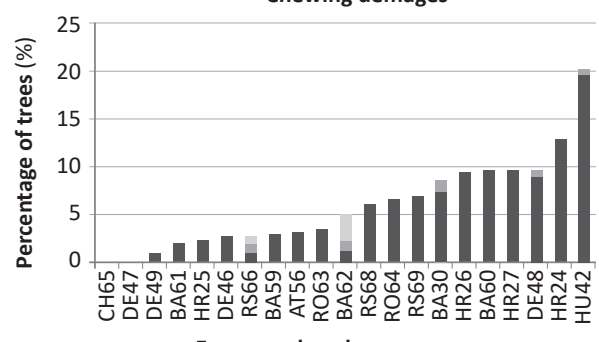

European beech provenances

$\square \mathrm{CD} 3(>50 \%) \quad \mathrm{CD} 2(10-50 \%) \quad \square \mathrm{CD} 1(<10 \%)$

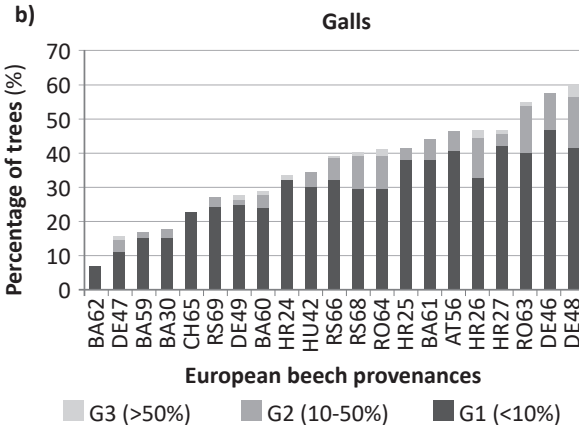

d)

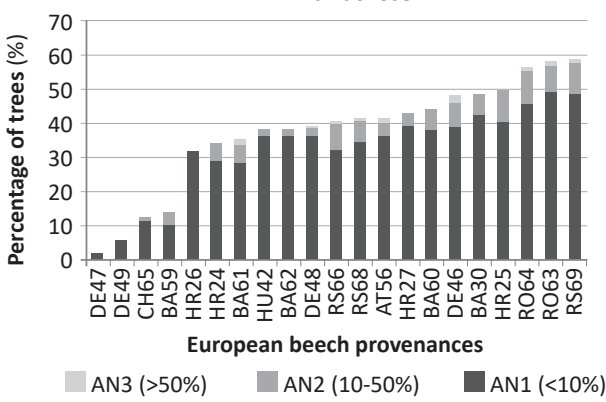

Figure 2. Intensity of crown damage by damage types: (a) aphids, (b) galls, (c) chewing damages, (d) anthracnose on European beech provenances (Coding label of provenances: see Table 1).

\section{Frequency and Provenance Clustering Based on Damage Types}

Frequency analyses of damage types are shown in frequency table (S3) and the mosaic map (Figure 4). According to damage frequency, anthracnose was the most common damage $(42.62 \%)$, followed by galls $(41.72 \%)$, canker $(7.88 \%)$, chewing damages $(7.02 \%)$, and aphids
$(0.76 \%)$. Anthracnose, galls and canker were found in each provenance. Provenances DE47 (0.09\%) and BA30 (3.23\%) were the least, HR25 (3.23\%) the most anthracnosedamaged provenances. The provenances that were the least and the most damaged by galls were BA62 (0.33\%) and DE48 $(3.75 \%)$, respectively. The lowest and the highest canker damages were observed on DE49 (0.09\%) and DE47 (0.85\%), 


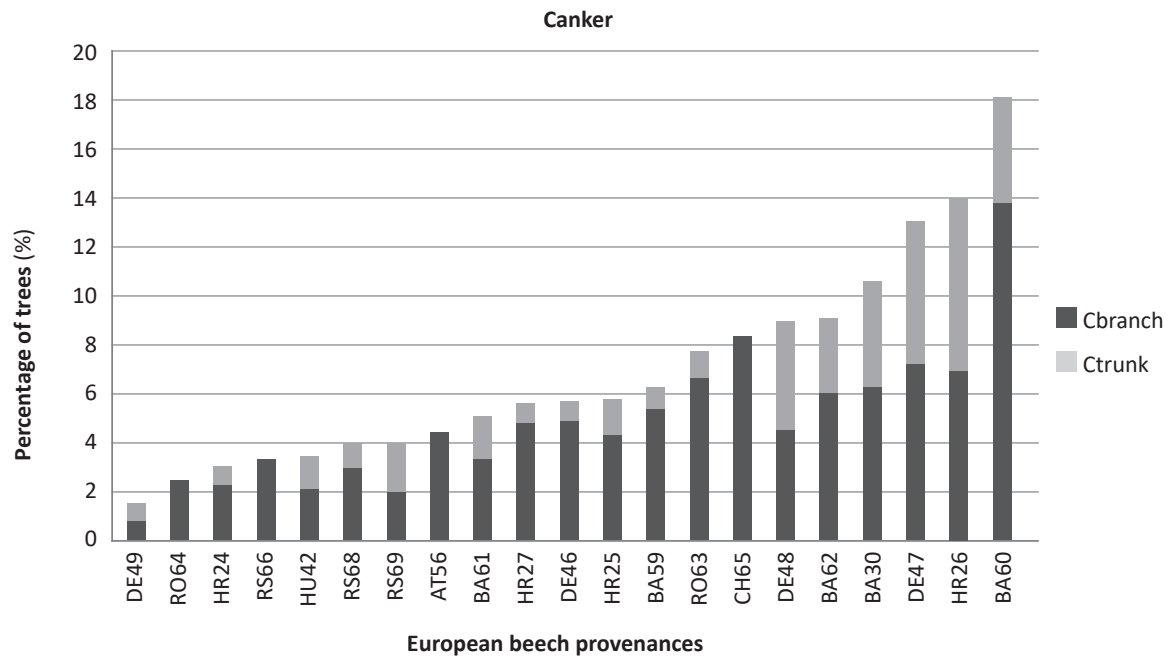

Figure 3. Percentage of canker per provenances (Coding label of provenances: see Table 1).

respectively. Chewing damages were detected in the range of $0.05 \%$ (DE49) to $1.38 \%$ (HU42) in most provenances, except for DE47 and $\mathrm{CH} 65$. Aphids were detected in the range from $0.05 \%$ to $0.14 \%$ in 11 provenances: AT56, BA30, HR26, DE48, DE49, CH65, RS66, HU42, HR24, RO64, and BA61. In the absence of aphid damage, the statistical chisquare test for damage to European beech provenances showed that there were significant statistical differences between provenances based on damage types (sample size=2091, $\chi 2=322.19 ; p<0.0001$ ). Thus, the dominant types of damage, anthracnose and galls, showed a total frequency of $84.34 \%$, while canker, chewing damages, and aphids showed a total frequency of $15.66 \%$.

The European beech provenances were grouped into four clusters based on damage type (Figure 5-7). Cluster 1 was characterized by the highest damage type of galls, followed in descending order by anthracnose, chewing damages, canker, and aphids. Cluster 1 included six provenances from Southeast Europe: R063, BA61, HR24, HR26, RS68, and RS66, as well as one from Central Europe, HU42. Cluster 2 was characterized by the highest damage type by galls, followed in descending order by anthracnose, canker, chewing damages, and aphids. Cluster 2 included three Central European provenances (DE49, CH65, DE47) and Southeast European provenance BA59. Cluster 3 was characterized by the highest damage type due to galls, followed in descending order by anthracnose, chewing damages, canker, and aphids. Cluster 3 consisted of ten provenances from Central and Southeast European origins: DE48, HR27, AT56, DE46, HR25, RO64, BA30, BA60, BA62, and RS69. Cluster 4 was characterized by the highest anthracnose damage, followed in descending order by galls, canker, chewing damages, and aphids. Cluster 4 consisted of Southeast European provenances BA30, BA60, BA62 and RS69. Based on these data, aphids and galls caused the least and most damage, respectively, in all clusters except Cluster 4, where anthracnose caused the most damage. Provenances from Southeast Europe and Central Europe predominated in Cluster 1 and Cluster 2, respectively. Cluster 3 contained provenances from both origins. Cluster 4 was the smallest and most homogeneous, consisting of Southeast European provenances at approximately the same latitude $\left(44^{\circ} 06^{\prime} \mathrm{N}-44^{\circ} 33^{\prime} \mathrm{N}\right)$. Taken together, the provenances (DE46, HR25, HR27, AT56, R064 and DE48) with the most damaged trees were grouped in Cluster 3 whereas the provenances (DE49, DE47, CH65 and BA59) with the least damaged trees were grouped in Cluster 2. The Central and Southeast European provenances did not form discrete clusters based on clustering analysis.

The international European beech provenance trial was set up with a different number of representative provenances from each country. Germany was represented by four provenances. Two of the German provenances, the southwestern (DE46) and the southeastern (DE48) provenances, were assigned to Cluster 3 and the other two provenances (DE49 and DE47) to Cluster 2. DE49 originated from the northern part of Germany and was the northernmost provenance in the entire provenance trial. The other three German provenances were from the southern part of the country. The southernmost provenance was DE47 with the lowest damage among the German provenances, but the highest canker damage among the 21 provenances. The German provenances showed the highest susceptibility to galls, followed in descending order by anthracnose, canker, chewing damage, and aphids. The Swiss provenance $(\mathrm{CH} 65)$ originated from the northwest of the country, near the French border, and was grouped into Cluster 2. Interestingly, chewing damage was not observed on $\mathrm{CH} 65$. Canker was the highest damage type of $\mathrm{CH} 65$, followed in descending order by galls, anthracnose and aphids. The Austrian provenance (AT56) was from the central part of the country and was grouped to Cluster 3. The highest damage type of AT56 was galls, followed in descending order by anthracnose, canker, chewing damage and aphids. Hungarian provenance (HU42) from the country's southwestern region, close to the Croatian border, 


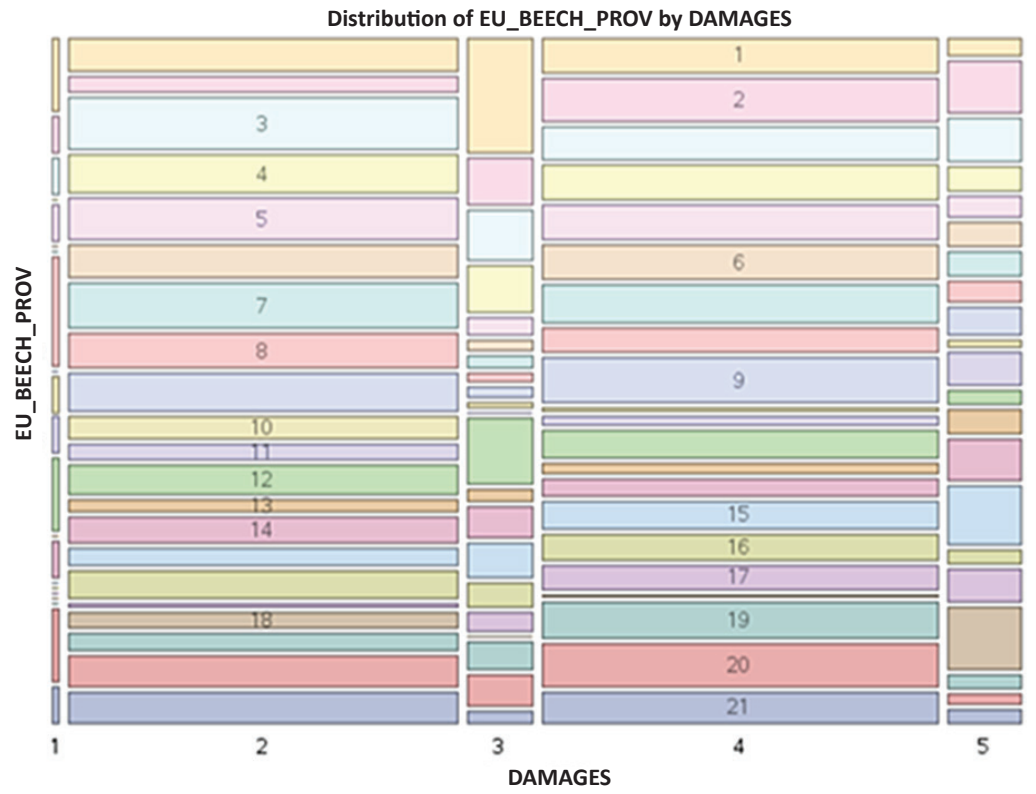

Figure 4. Mosaic plot of the distribution of damage types in European beech provenances based on S3. Axis X: 1. Aphids, 2. Galls, 3. Chewing damages, 4. Anthracnose, 5. Canker. Axis Y European beech provenances 1. HU42, 2. BA30, 3. DE48, 4. HR27, 5. AT56, 6. RO63, 7. DE46, 8. BA61, 9. HR25, 10. DE49, 11. CH65, 12. HR24, 13. BA59, 14. HR26, 15. BA60, 16. RS68, 17. BA62, 18. DE47, 19. RS69, 20. RO64, 21. RS66 (Coding label of provenances: see Table 1).

Tre diagram for 21 cases complete linkage euclidean distances

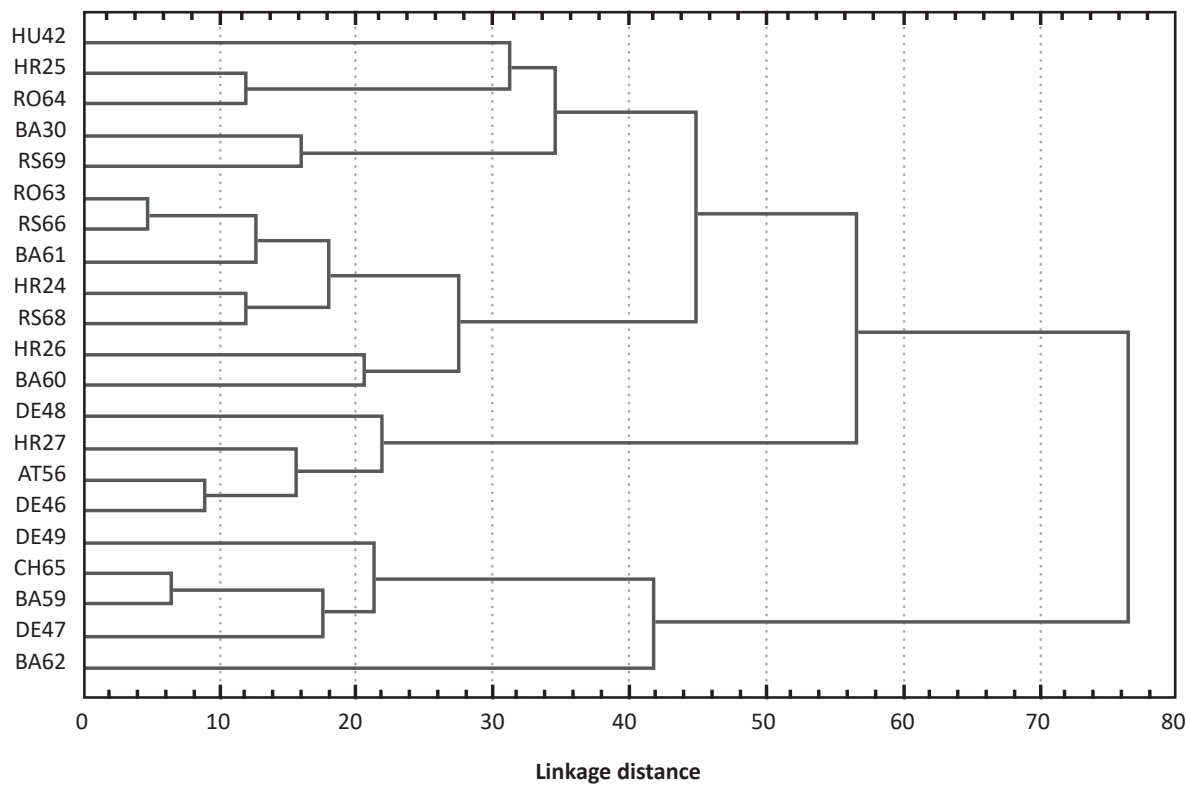

Figure 5. Dendrogram of 21 European beech provenances using five types of damage (aphids, galls, chewing damages, anthracnose and canker) produced by cluster analysis (complete linkage, Euclidean distance) using a cut point with four clusters (Coding label of provenances: see Table 1). 


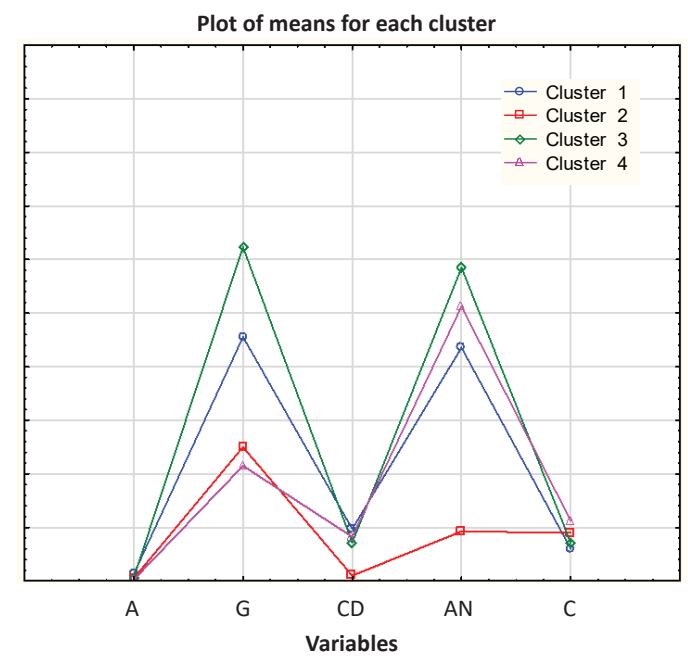

Figure 6. The plot of means for clusters of damage (X axis: AAphids, G-Galls, CD-Chewing damages, AN-Anthracnose, C-Canker, $Y$ axis: \% of damaged trees) of European beech provenances using the non-hierarchical k-means procedure.

was grouped into Cluster 1 . The highest damage type of HU42 was anthracnose, followed in descending order by galls, chewing damages, canker and aphids. Two of the four Croatian provenances (HR26 and HR27) originated from the southwestern part of the country. HR26 originated from the Istrian peninsula. The remaining two provenances (HR24 and HR25) originated from the eastern part of the country, Slavonia. Interestingly, HR 24 and HR26 were grouped in Cluster 1, HR25 and HR27 were grouped in Custer 2. HR25 was the most damaged. HR26 was the least damaged provenance. Galls were the highest damage type of the Croatian provenances, followed in descending order by anthracnose, chewing damage, canker and aphids. Bosnia and Herzegovina had the highest number of provenances. They were divided into three clusters: Cluster 1 (BA 61), Cluster 2 (BA59), and Cluster 4 (BA 62, BA60 and BA30). BA61 was the most damaged while BA62 was the least damaged. The highest damage type was anthracnose, followed in descending order by galls, canker, chewing damages and aphids. Serbia was represented by three provenances originating from the centre of the country. Two of the provenances were grouped into Cluster 1 (RS68 and RS66) and one provenance (RS69) was grouped into Cluster 4. RS66 was the most damaged provenance and RS68 was the least damaged provenance. Canker was present in all three provenances to the same extent. The highest damage type was anthracnose, followed in descending order by galls, chewing damages, canker and aphids. Romania had two provenances, RO63 and R064, which were grouped into Clusters 1 and 3, respectively. They originated from the western part of the country. The highest damage type was anthracnose, followed in descending order by galls, chewing damages, canker and aphids. Thus, anthracnose and galls were the dominant damage types in all countries except for the Swiss provenance ( $\mathrm{CH} 65)$ where canker was the dominant damage type. Furthermore, the provenances of one particular country were generally classified into several clusters.

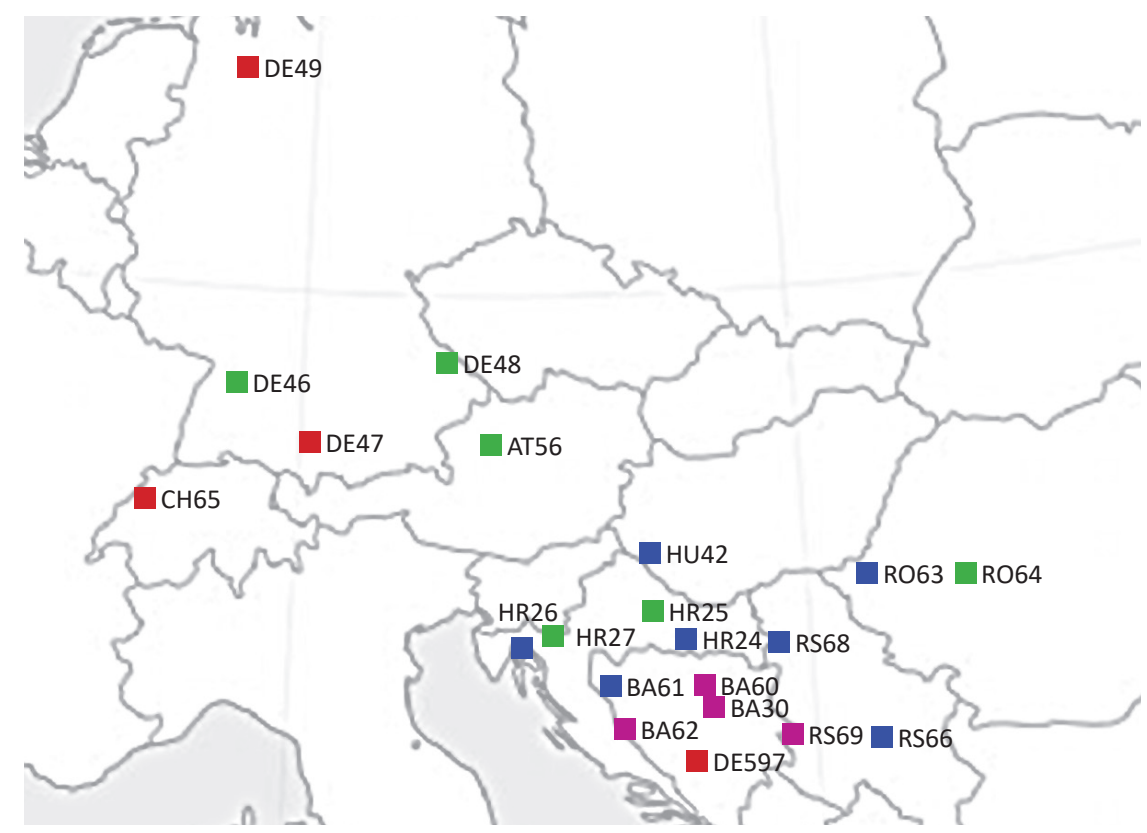

Figure 7. Map of origin of European beech provenances (coloured rectangles) of the provenance trial located in Croatia, Medvednica Mountain (black triangle). The colours represent different clusters of provenances analysed by the non-hierarchical k-means procedure: Cluster 1, blue; Cluster 2, red; Cluster 3, green; and Cluster 4, violet (Coding label of provenances: see Table 1). 


\section{DISCUSSION}

The health condition of the European beech is concerning due to climate change. We investigated the health condition of European beech provenances in field trial located on Medvednica Mountain in Croatia. Medvednica Mountain in a natural environment for European beech covering $63.6 \%$ of the forest area. Thus, the provenance trial grows under the influence of abiotic and biotic environmental factors of the natural distribution area of this tree species. In addition, the international character of the provenance trial provided the opportunity to compare European beech provenances from Central and Southeast Europe.

The insect damages (aphids, galls and chewing damages) and damages from the fungal diseases (anthracnose and canker) of European beech provenances were almost equally represented (S3). Similar types of damage have already been reported (Gossner et al. 2014). Frequency analysis revealed that the presence of aphids was very low, less than $1 \%$, while chewing damages were in the range of $10 \%$ and galls in the range of $50 \%$ (S3). Notably, aphids have a complicated life cycle with multiple developmental stages and morphology, and about ten generations of aphids of wingless and winged forms emerge annually in the ascending season (Van Driesche 2012). Sexual reproduction occurs in the autumn when eggs are produced for overwintering. In addition, aphid reproduction is more temperature-dependent than aphid generation (Ivrsen and Hardig 2007). The development of galls is promoted by light, warm temperatures and dry periods (Kelch 2016). Adult M. fagi leave the galls and mate in spring. The female lays eggs in April. The galls are welldeveloped by June. In autumn, the galls fall from the leaves with the larvae and overwinter on the ground. Considering the analysed meteorological data of Medvednica Mountain, the winter of 2015 was cold, with mean temperature between $-0.2^{\circ} \mathrm{C}$ and $2.1^{\circ} \mathrm{C}$ from January to March. During the winter of 2015, most snowfalls occurred in January, February, and March (S4b). Thus, the high mortality of insects was favoured by low winter temperatures, as confirmed by the low percentage of trees affected by aphids and chewing damages. Galls affected a higher percentage of trees than aphids, indicating better overwintering of $M$. fagi larvae compared to aphid eggs. However, the milder winters and less snowpack will favour propagation and survival of the beech scale, as Stephonson and Ribarik Coe (2017) stated. Fungi are spread by wind and insects. They invade plants through wounded tissue, although they also enter through natural openings such as stomata, hydathodes, and lenticels. For infection, fungi require humidity, and fungal diseases are most commonly reported during rainy weather events (Bahnweg et al. 2005). Apiognomonia errabunda causes disease symptoms in leaves and twigs, resulting in premature leaf loss and the dieback of young shoots (Butin 1995). It occurs in buds, bud scales, and the bark of twigs and stems during the growing season (Sieber and Hugentobler 1987, Kowalski and Kehr 1996), sometimes without any disease symptoms (Petrini 1991, Sinclair and Cernauskas 1996, Stone et al. 2000). The fungus overwinters in leaf and branch canker tissue, and infection of emerging leaves occurs in the following spring by spores. However, the degree of destruction is highly dependent on climatic factors. During budburst and early leaf formation, constant temperatures of $10^{\circ} \mathrm{C}-14^{\circ} \mathrm{C}$ are essential for spore growth and infection. During this period, higher or lower average temperatures reduce disease severity. Thus, the average temperatures on Medvednica Mountain were below $10^{\circ} \mathrm{C}$ in March and April 2015, indicating unfavourable conditions for spore development. In May, the average temperature was above $10^{\circ} \mathrm{C}(\mathrm{S} 4 \mathrm{a})$, favouring spore development. In addition, $A$. errabunda requires water to spread and infect; it does not spread under dry conditions. During the period of budburst and spore production in the early spring in April, the aridity index was semi-humid. The aridity indices ranged from extremely humid in May to humid in June (S4c). As a result, anthracnose was found in more than $40 \%$ of the damaged trees (S3) because of the high humidity.

Canker diseases are caused by the fungi Nectria cinnabarina and Nectria ditissima. N. cinnabarina is indicated by branch necrosis and dieback of young stems. In contrast, $N$. ditissima causes cankers on the trunk. These pathogens attack weakened trees under stressful conditions such as frost, drought, physical damage and fungal influence. They are saprophytes and weak parasites. Sites of infection include frost-damaged beech bark, bits of rodents or game, and openings such as lenticels (Montecchio 2011). Once the canker has infected the branch, dieback cannot be prevented. In beech forest stands, canker affects beech more frequently at lower altitudes and warm and dry areas (Metzler and Erffa 2000). In the present study, a low percentage of trees, ranging from $0.09 \%$ (DE 49 ) to $0.81 \%$ (BA60), were infested at low intensity (less than $10 \%$ ) by $N$. cinnabarina and $N$. ditissima (Figure 3 ).

Clustering analysis allowed the grouping of provenances into four clusters, showing no grouping of Central and Southeast European provenances into separate clusters. Cluster 2 consisted of three Central European provenances (DE49, DE47 and $\mathrm{CH} 5$ ) and Southeast Europa provenance BA59, while Cluster 3 consisted of three Central European provenances (DE46, DE48 and AT56) and Southeast European provenances (HR25, HR27 and R064). Cluster 4 was composed of Southeast European provenances, mostly from Bosnia and Herzegovina (BA62, BA60 and BA39), and including one provenance from Serbia (RS69). Central and Southeast European provenances, as well as the provenances of each country, could not be clearly separated according to damages by cluster analysis.

Three factors should be present to support diseases, constituting a disease triangle: one side of the triangle is the host plant, the other side is the disease-causing organism, and the third side are the environmental conditions (Stevens 1960, Francl 2001). Considering the environmental conditions at the provenance trial location, European beech grows in an optimal habitat that ensures good physiological conditions for tree growth and development. The local climate on Medvednica Mountain is continental, typical for the Central European mountains, with high precipitation and low temperatures. The maximum precipitation occurs during the warm season. This type of climate has been called "the climate of beech" (Šegota and Filipčić 1996). Thus, damaging insects and pathogenic fungi were presented at low intensity 
in this provenance trial due to the significant number of days with low temperatures, snow and frost in 2014 and 2015.

The limitations of this study should be acknowledged. Data collection was conducted on an unequal number of provenances from each country. Bosnia and Herzegovina was represented by five provenances, Germany and Croatia by four provenances. Serbia and Romania were represented by three and two provenances, respectively. Switzerland, Austria, and Hungary were represented by one provenance. Therefore, the results refer only to these provenances and cannot be generalized. In addition, this study provided an overview of damage types occurring in the middle of the vegetation period (July 2015). Future multi-seasonal and multi-annual studies will obtain a broader picture of damage types and intensity.

\section{CONCLUSIONS}

The results of this study provide information on the health condition of the International European beech provenance trial on Medvednica Mountain in Croatia. Tree survival was very high, with a predominance of healthy trees and a dominance of one disease per damaged tree. The five types of damages analysed were mostly present at low intensity (less than 10\%). Anthracnose and galls were the most common damages, followed in descending order by chewing damage, canker, and aphids. Statistically significant differences in damage were found among provenances $\left(\chi^{2}=322.19, p<0.0001\right)$. Cluster analysis of provenances according to damage showed four clusters. However, clustering did not separate Central European from Southeast European provenances, since both were found in the less and the most damaged cluster. Besides, the provenances of individual countries were clustered into multiple clusters. The favourable climatic and environmental conditions at the location of the provenance trials resulted in the good health of the European beech trees. These data are important for the projection of European beech forest survival and maintenance of the good quality of the forest stand. Considering climate change, continuous monitoring of the occurrence of European beech damage is necessary, drawing particular attention to extreme events.

\section{Author Contributions}

$\mathrm{MI}, \mathrm{SNA}, \mathrm{NC}$ and MGP conceived and designed the research, SNA, NC, ML and SB carried out the field measurements, NC processed the data, $\mathrm{NC}$ and $\mathrm{AJ}$ performed the statistical analysis, $\mathrm{MI}$ secured the research funding, supervised the research, MI, MGP, AD, and HR helped to draft the manuscript, NC, SNA, and AJ wrote the manuscript.

\section{Funding}

This work has been fully supported by Croatian Science Foundation under the project Conservation of forest tree gene pool in the light of climate change, HRZZ /IP-2013-11-8131 / ConForClim.

\section{Acknowledgments}

The study was performed on an International European beech provenance trial on Medvednica Mountain as a part of the project "Forest tree Breeding and Seed husbandry" (024-2421082099) funded by The Ministry of Science and Education of Croatia in collaboration with Croatian Forest Ltd. The authors thank dr. sc. Ivan Medved Assistant Professor at University of Zagreb, Faculty of Mining, Geology and Petroleum Engineering for the expertise provided to create the map using QGIS software, version 2.16.).

\section{Conflicts of Interest}

The authors declare no conflict of interest.

\section{Supplementary Materials}

Supplementary File 1. Percentage of surviving and healthy trees of the international European beech provenance trail.

Supplementary File 2. Damage types observed on the international European beech provenances trial: (a) Phillaphis fagi on the leaf, (b) chewing damages - bitten parts of leaf, (c) leafmining, (d) galls of Mikiola fagi on leaf, (e) Anthracnose on leaf, (f) Canker on beech steam.

Supplementary File 3. Frequency table data of European beech provenances in the international European beech provenance trial.

Supplementary File 4. Meteorological data obtained from the Croatian Meteorological and Hydrological Service weather station Puntijarka in 2014-2015: (a) Monthly precipitation (MP), maximum (Max), average (AMT), and minimum (Min) monthly temperatures, (b) Snow and frost data, (c) Monthly de Martonne aridity index.

\section{REFERENCES}

Arač K, 2010. Decay fungi of living European beech trees. In: Proceedings of International Scientific Symposium Is there future for beech - changes, impacts and answers (FAGUS 2010). Varaždin, Croatia and Zala County, Hungary, 27-29 October 2010, pp 150-152.

Arač K, 2016. Occurrence and damaging impact of fungus Meripilus giganteus (Pers) P Karst on Europaen beech (Fagus sylvatica L.) PhD Thesis, University of Zagreb, Faculty of Forestry.

Bahnweg G, Heller W, Stich S, Knappe C, Betz G, Heerdt C, Rothenburger J, 2005. Beech leaf colonization by the endophyte Apiognomonia errabunda dramatically depends on light exposure and climatic conditions. Plant Biol 7(6): 659-669. https:// doiorg/101055/s-2005-872943.
Bogunović S, Bogdan S, Lanšćak M, Ćelepirović N, Ivanković M, 2020. Use of a Common Garden Experiment in Selecting Adapted Beech Provenances for Artificial Stand Restoration. South-east Eur for 11(1): 1-10. https://doiorg/1015177/seefor20-07

Bolte A, Czajkowski T, Kompa T, 2007. The north-eastern distribution range of European beech-a review. Forestry 80: 413-429. https:// doiorg/101093/forestry/cpm028.

Bréda N, Huc R, Granier A, Dreyer E, 2006. Temperate forest trees and stands under severe drought a review of eco-physiological responses adaptation processes and long-term consequences. Ann For Sci 63: 625-644. https://doiorg/101051/forest:2006042.

Butin H, 1995. Tree Diseases and Disorders. Oxford University Press, Oxford, UK, 262 p. 
De Martonne, 1926. E Aerisme et índices d'aridite. C R Acad Sci 182: 1395-1398.

Diminić D, 2003. Fungal diseases of Common beech. In: Matić S (ed) European beech (Fagus sylvatica L.) in Croatia. Croatia Academy of Forestry Sciences, Zagreb, Croatia, pp 549-560.

Fang J, Lechowicz MJ, 2006. Climatic limits for the present distribution of beech (Fagus L.) species in the world. J Biogeogr 33(10): 18041819. https://doiorg/101111/j1365-2699200601533x.

FAO, 2009. Global review of forest pests and diseases. FAO, Rome, Italy.

Francl LJ, 2001. The disease triangle: a plant pathological paradigm revisited. Plant Health Instr $10 \mathrm{p}$.

Gessler A, Keitel C, Kreuzwieser J, Matyssek R, Seiler W, Rennenberg $\mathrm{H}, 2007$. Potential risks for European beech (Fagus sylvatica L.) in a changing climate. Trees 21: 1-11. https://doiorg/101007/s00468006-0107-x.

Gömöry D, Paule L, Vyšný J, 2007. Patterns of allozyme variation in western Eurasian Fagus Bot J Linn Soc 154(2): 165-174. https:// doiorg/101111/j1095-8339200700666x.

Gossner MM, Pašalić $E$, Lange $M$, Lange $P$, Boch $S$, Hessenmöller $D$, Weisser WW, 2014. Differential responses of herbivores and herbivory to management in temperate European beech. PloS one 9(8). https://doiorg/101371/journalpone0104876.

Gračan J, Ivanković M, Matić S, Krpan A, 2001. The first growth results of beech (Fagus sylvatica L.) provenances in Croatia. In: Matic S, Krpan APB, Gračan J (eds) Science in sustainable management of Croatian forests. Forest Research Institute, Jastrebarsko, Croatia, pp 175-190.

Harapin M, 2003. Harmful factors and integral protection of common beech. In: Matić S (ed) Common beech (Fagus sylvatica) in Croatia. Academy of Forestry Sciences, Zagreb, Croatia, pp. 594-598.

Hrašovec S, 2003. The entomological complex of common beech. In: Matić S (ed) Common beech (Fagus sylvatica) in Croatia. Academy of Forestry Sciences, Zagreb, Croatia, pp 537-548.

Ivanković M, Bogdan S, Božič G, 2008.a European beech (Fagus sylvatica L.) height growth variability in Croatian and Slovenian provenance trials. Šum List 11-12: 529-541.

Ivanković M, Bogdan S, Littvay T, 2008.b Genetic variation of flushing and winter leaf retention in European beech provenance test in Croatia In: Proceedings of The 8Ih IUFRO International Beech Symposium ÍUFRO working party 10107 Ecology and Silviculture of Beech, Nanae, Hokkaido, Japan; 8-12 September 2008. pp 28-30.

Ivanković M, Bogdan S, Gračan J, Bogdan S, 2010. Current Status of European Beech (Fagus sylvatica L.) Genetic Resources in Croatia. Commun Inst For Bohem 25: 70-77.

Iversen T, Harding S, 2007. Life table parameters affecting the population development of the woolly beech aphid Phyllaphis fagi. Entomol Exp App/ 123(2): 109-117. https://doiorg/10.1111/j.15707458.2007.00524.x.

Kelch NS, Neves FS, Fernandes GW, Wirth R, 2016. Mechanisms driving galling success in a fragmented landscape: synergy of habitat and top-down factors along temperate forest edges. PloS one 11(6): e0157448. https://doi.org/10.1371/journal.pone.0157448.

Kowalski T, Kehr RD, 1996. Fungal endophytes of living branch bases in several European tree species In: Redlin SC, Carris LM, St Paul MN (eds) Endophytic Fungi in Grasses and Woody Plants: Systematics Ecology and Evolution. APS Press, St Paul, Minnesota, USA, pp 6786.

Kramer K, Degen B, Buschbom J, Hickler T, Thuiller W, Sykes MT, 2010. Modelling exploration of the future of European beech (Fagus sylvatica L.) under climate change Range abundance genetic diversity and adaptive response. For Ecol Manag 259: 2213-2222. https://doiorg/101016/iforeco2009 12023.

Mátyás C, Bozic $\mathrm{G}$, Gömöry D, Ivanković M, Rasztovits E, 2009. Juvenile growth response of European beech (Fagus sylvatica L.) to sudden change of climatic environment in SE European trials. IForest 2(6): 213. https://doiorg/103832/ifor0519-002.

Metzler B, Erffa RFV, 2000. Zur Verbreitung von Buchenkrebs in Naturverjüngungen in Baden-Württemberg. Forstw Cb/ 119: 297309. https://doiorg/101007/BF02769144.
Montecchio L, Scattolin L, De Battisti R, 2011. Dormouse injuries predispose beech to infection by Neonectria ditissima. For Pathol 41(2): 114-119. https://doiorg/101111/i1439-0329201000643x.

Muhs HJ, Wuehlisch GV, 1993. The scientific basis for the evaluation of the genetic resources of beech. In: Proceedings of a scientific workshop under the Community Research Programme on Agriculture and Agro-Industry including Fisheries (AIR). Commission of the European Communities, Ahrensburg, Germany, 1-2 July 1993, $267 \mathrm{p}$.

Pernek M, Županić M, Diminić D, Cech T, 2011. Phytophthora species on beech and poplars in Croatia. Šum List 135(13): 130-137.

Petrini O, 1991. Fungal endophytes of tree leaves In: Microbial ecology of leaves. Springer, New York, NY, USA, pp 179-197. https://doio $\mathrm{rg} / 10.1007 / 978-1-4612-3168-49$.

Pilaš I, Medved I, Medak J, Perčec Tadić M, Medak D, 2016. Ecological Typological Properties and Photosynthetic Activity (FAPAR) of European Beech (Fagus sylvatica L) Ecosystems in Croatia. Southeast Eur for7(2): 73-89. https://hrcaksrcehr/170295.

Potočić N, Seletković I, Ugarković D, Jazbec A, Mikac S, 2008. The influence of climate properties on crown condition of European beech (Fagus sylvatica L.) and Silver fir (Abies alba Mill.) on Velebit. Period Biol 110(2): 145-150. https://hrcaksrcehr/29506.

Rennenberg H, Seiler W, Matyssek R, Gessler A, Kreuzwieser J, 2004. European beech (Fagus sylvatica L.) - a forest tree without future in the south of Central Europe? Allg Forst Jagdztg 175: 210-224.

Seletković I, Potočić N, Ugarković D, Jazbec A, Pernar R, Seletković A, Benko M, 2009. Climate and relief properties influence crown condition of common beech (Fagus sylvatica L.) on the Medvednica massif. Period Biol 111(4): 435-441.

Sieber T, Hugentobler C, 1987. Endophytic fungi in leaves and twigs of healthy and diseased beech trees (Fagus sylvatica L.) Eur J Plant Pathol 17(7): 411-425.

Sinclair JB, Cernauskas RF, 1996. Latent infection vs endophytic colonization by fungi Endophytic Fungi. In: Redlin SC, Carris LM (eds) Grasses and Woody Plants: Systematics Ecology and Evolution. APS Press, St Paul, Minnesota, USA, p. 3-29.

Sokal RR, Rohlf FJ, 1995. Biometry. $3^{\text {rd }}$ edn. Freeman and Company, New York, USA.

Stephanson CA, Ribarik Coe N, 2017. Impacts of beech bark disease and climate change on American beech. Forests 8(5): 155

Stevens RB, 1960. Cultural practices in disease control. In: Horsfall JG, Dimond AE (eds) Plant pathology an advanced treatise. Volume 3. Academic Press, NY, pp 357-429.

Stone JK, Bacon CW White JF, 2000. An overview of endophytic microbes: Endophytism defined. In: Bacon CW, White JF (eds) Microbial Endophytes. 1st edn. Marcel Dekker, New York, pp 17-44.

Šegota T, Filipčić A, 1996. Climatology for geographers. Školska knjiga, Zagreb, Croatia, $471 \mathrm{p}$.

Tomiczek C, Perny B, Cech TL, 2006. Zur Waldschutzsituation der Buche. BFW Paxisinformation 12: 19-21.

Turok J, Kremer A, de Vries S, 1998. First EUFORGEN Meeting on Social Broadleaves Bordeaux, France 23-25 October 1997, International Plant Genetic Resources Institute, Rome, Italy, pp 1-176.

Unterseher M, Siddique AB, Brachmann A, Peršoh D, 2016. Diversity and composition of the leaf mycobiome of beech (Fagus sylvatica) are affected by local habitat conditions and leaf biochemistry. PloS one 11(4): e0152878. https://doiorg/101371/journalpone0152878

Van Driesche RG, 2012. The role of biological control in wildlands, Biol Control 57(2): 131-137.

Vukelić J, Rauš $Đ, 1998$. Forest Phytocenology and Forest Communities in Croatia, University of Zagreb, Faculty of Forestry, Zagreb, Croatia, $310 \mathrm{p}$.

Wühlisch, 2008. G EUFORGEN Technical Guidelines for genetic conservation of European beech (Fagus sylvatica). Bioversity International, Rome, Italy, pp 1-6.

Wühlisch G, 2010. Genetic resources of beech in Europe - current state. Commun Inst For Bohem 25: 8-9.

Zaninović K, Gajić-Čapka M, Perčec Tadić M, Vučetić M, Milković J, Bajić A, Likso T, 2008. Climate atlas of Croatia: 1961-1990. 1971-2000. Meteorological and Hydrological Service, Zagreb, Croatia. 
